\title{
ВКЛАД ЦЕРКВИ В ОРГАНИЗАЦИЮ АНТИАЛКОГОЛЬНОЙ ПОЛИТИКИ \\ В ДОРЕВОЛЮЦИОННОЙ РОССИИ В КОНЦЕ ХІХ - НАЧАЛЕ ХХ ВВ. (НА ПРИМЕРЕ ОРЛОВСКОЙ ЕПАРХИИ)
}

На современном этапе российское общество вновь столкнулось с проблемой увеличения числа людей, зависимых от алкоголя. В истории было много примеров проведения антиалкогольных компаний. Современное общество привлекает различные методы воздействия. Это и наглядная пропаганда, и популяризация спорта, здорового образа жизни, и беседы среди молодежи, и запреты на законодательном уровне

Данная статья посвящена изучению отношения русской православной церкви к проблеме пьянства. В статье анализируется законодательная система конца XIX - начала XX вв. в деле борьбы с распространением алкогольной зависимости. Автор изучает деятельность «обществ трезвости», домов трудолюбия. В ходе исследования был проанализирован опыт работы Александро-Невского общества трезвости города Санкт-Петербурга.

В статье приведен опыт педагога-новатора и ярого борца с алкоголем С. А. Рачинского, его методика борьбы с пьянством среди молодежи. Автор подчеркивает, что борьба с пьянством была совместной. Правительство со Священным Синодом с 1911 г. проводит всероссийский день трезвости, вводит запрет на употребление спиртного, определяет нормы продажи. В процессе исследования были проанализированы различные методь борьбы с алкоголем. Изучается отношение прихожан к проблеме пьянства.

Новизна исследования состоит в том, что в статье особое внимание уделяется ситуации в Орловской губернии. Через анализ позиции Орловской епископа $\mathrm{Ce}$ рафим (Чичагов), отдельных приходских священников к антиалкогольной борьбе стало возможным более глубже изучить ситуацию в провинции. В ходе работы над статьей автор пришел к выводу, что церковь предъявляла особые жесткие требования к священнослужителям, которые своим правильным примером должны были убеждать народ отказаться от алкоголя. После оформления запрета на пьянство на законодательном уровне, церковь взяла на себя задачу - бороться с тайными и незаконными продажами алкоголя и любой ценой отвлечь народ от употребления водки.

Ключевые слова: алкоголизм, борьба с пьянством, дома трудолюбия, общество трезвости, Орловская епархия.

\section{O. V. Klevtsova}

\section{THE CONTRIBUTION OF THE CHURCH TO THE ORGANIZATION OF ANTI-ALCOHOL POLICY IN PRE-REVOLUTIONARY RUSSIA IN THE LATE XIX - EARLY XX CENTURIES (BY THE EXAMPLE OF THE OREL DIOCESE)}

At the present stage, Russian society has again faced the problem of increasing the number of people dependent on alcohol. There have been many examples of anti-alcohol companies throughout the history. Modern society uses different methods of influence. These are visual propaganda, promotion of sports, a healthy lifestyle, conversations among young people and bans at the legislative level.

The article studies of the attitude of the Russian Orthodox Church to the problem of drunkenness. The article analyzes the legislative system of the late $X I X$ - early $X X$ centuries in the fight against the spread of alcohol dependence The author studies the activity of "sobriety societies" and the houses of diligence. The study analyzes the experience of the Alexander Nevsky sobriety society in St. Petersburg

The article presents the experience of the teacher-innovator and an ardent fighter against alcohol S. Rachinsky, his method of extirpating drunkenness among young people. The author emphasizes that the fight against drunkenness was a joint action. The government with the Holy Synod since 1911 holds the all-Russian day of sobriety, introduces a ban on the use of alcohol, determines the norms of sale. Different methods of anti-alcohol actions are analyzed. The attitude of parishioners to the problem of drunkenness is analyzed

The novelty of the study is that the article focuses on the situation in the Orel province. Through the analysis of the position of the Orel Bishop Seraphim (Chichagov), some parish priests to the anti-alcohol struggle, it became possible to study the situation in the province more deeply. In the course of work on the article, the author concludes that the Church imposed special strict requirements on the clergy, who by their right example had to convince the people to give up drinking alcohol. After registration of the ban on drunkenness at the legislative level, the Church took on the task to fight the secret and illegal sales of alcohol and at any cost to distract people from the use of vodka.

Key words: alcohol addiction, fight against alcoholism, houses of diligence, society of sobriety, Orel diocese. 
Проблема алкоголизма в России в конце XIX начале $X X$ в. имела большой размах. Как справедливо заметил великий русский педагог С. А. Рачинский (1833-1902 гг.): «Пьянство в России приняло размеры, опасные для общества, для государства, для Церкви. Колоссальные опыты на Западе доказали, что единственное действенное орудие против этого зла - абсолютная трезвость» $[7$, с. 27-35].

И хотя с этой проблемой столкнулась не только наша страна, но и ведущие европейские государства, народ прекрасно понимал, что борьбу с недугом начинать надо сообща, с каждого отдельного человека. Самый большой процент подверженных алкогольной зависимости приходился на крестьянское сословие.

Священный Синод определил основные причины пьянства. Среди главных фракторов можно выделить: невежество и темнота народа; пример старших (начальствующих лиц, духовных наставников, народных деятелей); нормы поведения («пить водку допьяна не позорно и не преступно»); отсутствие доступных бедным людям развлечений; не желание стремиться к лучшему, к умственному просвещению [11, с. 128]

Церковь всегда занимала активную позицию в борьбе с общенародным недугом. В 50-Х гг. XIX в. Священный Синод благословлял священников воспитывать народ на своем собственном примере, с помощью проповеди «о пользе воздержания» $[12$, с. 125$]$.

Еще в 1858 г. в России создаются первые общества трезвости. Они были основаны на принципе добровольности и исполнения обета трезвости. Но инициатива вскоре сошла на нет [6, с. 63].

Одним из крупнейших обществ трезвости являлось Александро-Невское в Санкт-Петербурге. Оно было основано в 1898 г. на базе Общества распространения религиозно-нравственного просвещения при храме Воскресения Христова. Основной методикой борьбы с пьянством Александро-Невского общества было убеждение пьющих дать обещание воздержаться от употребления спиртных напитков. Это обещание давалось публично, во время богослужения. За первые 10 лет существования было дано 598000 трезвенных обещаний и проведено более 11650 бесед и поучений с прихожанами [1].

От этого недуга страдало не только старшее поколение. Современники указывали на то, что к спиртному приобщались и дети. Рачинский являлся не только новатором в педагогике, но и активным борцом за трезвость. Организуя работу школ в селе Татаево Бельского уезда Смоленской губернии, С. А. Рачинский столкнулся со страшной проблемой. «С самого начала моей школьной работы, я не мог не обратить внимания на вопиющее зло, причиняемое моим ученикам постоянным усилением пьянства в крестьянской среде... Для меня стало очевидным, что для ограждения моих учеников от окружающего зла нужны средства более сильные, чем простые увещевания и поучительные речи. И единственное средство, которое я мог придумать, было устройство в тесном кругу моих учеников (из коих многие в то время были уже взрослые) общество трезвости, т. е. абсолютного воздержания от спиртных напитков» $[7$, c. 65].

В конце XIX - начале XX вв. в стране повсеместно стали организовываться общества трезвости. Активную просветительскую работу о вреде пьянства в нашей стране проводил доктор Н. И. Григорьев, член Санкт-Петербургского Общества Трезвости, Почетный член Лондонского общества изучения пьянства. По его инициативе с 1 сентября 1894 г. в России стал выходить в свет первый ежемесячный журнал «Вестник трезвости». В нем печатались правительственные распоряжения о торговле, употреблении спиртных напитков, рассказывалось о деятельности отдельных Обществ трезвости, познавательные статьи о вреде пьянства и его последствиях, приводились рассказы, повести и стихи нравственного и исторического содержания

Журнал «Вестник трезвости» был допущен к печати особым отделом ученого комитета Министерства народного просвещения и рекомендован для учительских библиотек, семинарий и институтов, для бесплатных библиотек и читален, а также для народных чтений

В июле 1909 г. Священный Синод разработал меры в борьбе с пьянством:

- устраивать общества трезвости по образцу Александро-Невского в Санкт-Петербурге;

- привлекать к борьбе с пьянством церковно-приходские попечительства, церковные братства и приходские советы;

- усилить живую проповедь о вреде пьянства;

- восстановить вечернее богослужение, где таковых нет, с чтением акафистов Божией Матери и с общественным пением;

- устраивать религиозно-нравственные чтения с помощью волшебного фонаря;

- правлением семинарии необходимо проводить подготовку воспитанников к борьбе с пьянСтвом.

Священный Синод особое внимание уделял образу жизни священнослужителей. «Можно ли ожидать действенного, проникающего сердца человеческого, внушительного слова против пьянства от такого пастыря, который отличается невоздержанием и дозволяет себе в присутствие своих прихожан... излишнее употребление спиртных напитков... » $[12$, с. 125$]$.

Так, например, священник Тверской епархии Иоанн Белюстин среди причин распространенного в духовной среде порока пьянства указывал следующие: брак «не по взаимному сердечному влечению» и запрет на второй брак. Часто священник «принимается за чарку - сначала, чтобы заглушить горе, а потом чарка делается для него потребностью и обращается в страсть». Часто к употреблению спиртного подталкивали и сами прихожане, так как «при обходе почти в каждом доме священнику и его спутникам подавали рюмочку" [20, с. 18].

Именно поэтому, в первую очередь необходимо было искоренить недуг в духовной среде, там, где встречались такие случаи. 
C помощью исповеди священнослужитель может побороть тягу к алкоголю. Подверженные алкоголизму не выносят никаких внушений со стороны родственников. Эти беседы вызывают только гнев. Именно во время исповеди «священник должен обращать особое исключительное внимание на пьяниц» $[12$, с. 125]. Очень часто причиной пьянства служат семейные раздоры, священник должен дать правильный совет, помочь в проблеме.

Большую роль в просвещении о вреде алкоголя играла народная школа. «Задача каждой школы - приготовить и воспитать здоровое поколение». Церковь считала, что свободная от наук молодежь может заполнить «умственную и нравственную пустоту... спиртными напитками».

Пастырь должен «раскрыть перед детьми все безобразие и гибельность «зеленого змия». По окончанию школы, после таких бесед, дети попытаются сохранить заветы своего духовного отца и смогут избежать такой пагубной привычки.

Правительство совместно с церковью вело борьбу с пьянством на законодательный уровень. 11 сентября 1911 г. православные христиане вспоминают Усекновение главы святого Иоанна Предтечи. Он был обезглавлен по приказу царя Ирода во время пьяного пира. В этот день христиане постились и повсеместно закрывались питийные заведения и винные лавки. Именно в этот торжественный день петербуржское Алексанро-Невское общество трезвости проводило всероссийскую компанию в поддержку законопроекта о мерах борьбы с пьянством, подготовленным III Государственной Думой. В соответствие с данным законопроектом правом на запрет продажи алкоголя теперь наделялись волостные, сельские сходы, городская дума и другие органы местной власти. Впервые в истории правом голосовать за принятие ограничений в продажи спиртного наравне с домохозяевами получили жены и матери Они были более заинтересованы в ограничении пьянства.

Вводился запрет на продажу алкоголя в субботние и предпраздничные дни после 14.00 часов Полный запрет на продажу алкоголя вводился в воскресные и праздничные дни. Теперь определялось расположение мест продажи спиртного. В столичных и губернских городах такие магазины можно было встретить за 40 сажень и более от церкви, учебных заведениях. В сельской местности не ближе 100 сажень (213 м). Помимо этого в учебных заведениях повсеместно необходимо было проводить беседы о вреде алкоголя.

После долгого обсуждения, доработок антиалкогольный закон так и не был принят, но многие принципы данного проекта постепенно прочно вошли в жизнь дореволюционного общества [2, c. 64].

B состав Орловской губернии в конце XIX начале XX вB. входили территории Болховского Брянского, Дмитровского, Елецкого, Карачаевского, Кромского, Ливенского, Малоархангельского, Мценского, Оловского, Севского, Трубчевского уездов. В губернии, по данным 1896 г. работало
22 виннокуренных заводов, 6 пиво-медоваренных и 3 водочных завода [7, с. 18]. Они приносили доход на сумму 1.937 .814 руб. [15, с. 20].

Житель села Подзовалово Болховского уезда Орловской губернии Н. Григорьев сообщает, что в конце XIX в.: «В престольный праздник, Успение, пьянство начинается сразу же после обедни и продолжается 2-3 дня. Крестьяне небольшими группами ходят друг к другу и везде выпивают водку. Часто в нее для крепости подмешивают нюхательный табак. Многие пьют до тех пор, пока не свалятся» [3].

Церковь занимала активную позицию в борьбе с распространением в губернии пьянства. Священномученик Преосвященнейший епископ Серафим (в миру Леонид Михайлович Чичагов) правящий архиерей Орловской епархии с 3 февраля 1906 а. по 16 сентября 1908 г. стремился просвещать народ о вреде алкоголя.

В своем труде «О возрождении приходской жизни» епископ Серафим указывал на одну из причин, осложняющих организацию прихода - увеличение пьянства. Епископ подчеркивает, что «народный грех приостановлен Самодержавным Царем», путем введение винной монополии. Теперь основной задачей церкви и приходских советов стало «борьба с тайною продажею вина и изготовлением крепких напитков». Епископ Серафим утверждает, что каждому крестьянину знаком человек, торгующий тайно спиртным. Людям, вынужденным торговать спиртным по бедности, необходимо помочь, чтобы они больше этим не занимались. Епископ призывает организовывать совместную борьбу с местными кулаками «одержимые духом сребролюбия и наживы». Торговцы часто были способны на месть - устраивали поджоги противникам, именно поэтому с ними боялись бороться. Епископ Серафим предложил повсеместно в епархии внедрять следующие методы:

1. Донести до торговцев и прихожан информацию «до какого нравственного падения доходит русский народ благодаря усилившемуся потреблению вина. Каждый благомыслящий человек должен воспротивиться такому разрушению народной нравственности, и все трезвые верующие, соединяясь между собою во имя Бога, православной веры, своего царя - помазанника Божия и возлюбленной родины, обязаны положить конец этой беде, угрожающей благосостоянию всей России и крепости государства».

2. Повсеместно создавать объединения «благомыслящих прихожан», организовывать собрания, привлекать женщин, детей, которые страдают от пьяниц дома.

3. В период формирования объединений необходимо с помощью миссионерских кружков и приходских советов воздействовать на «тайных продавцов». Священнослужитель должен мирным путем, через исповедь, беседы с глазу на глаз объяснить торговцу, что он занимается воровством, торгую запрещенными напитками.

4. После объединения всех желающих в борьбе с пьянством, следует проводить беседы с тайными торговцами на сельском сходе, просить их 
«бросить это занятие как недостойное и преступное». Если и эти меры не будут иметь успеха, то отлучать их от прихода.

5. Если и после этих мер торговля спиртным будет продолжаться, то требовать прекращения торговли «под угрозою предания виновных властям для законного суда».

Епископ Серафим очень надеялся на то, что здравый смысл, усердие священников будут иметь результат. Церковь призывала открывать в городах и селах общества трезвости и призывала уменьшать употребление алкоголя на свадьбах и других праздниках, а также во время помина усопших [19].

Общества трезвости в конце XIX в. были организованны в Болховском, Мценском, Елецком и Карачевском уездах [17]. Церковно-приходские общества трезвости Орловской губернии было представлен в Трубчевском уезде, в селе Субботово. Это общество было открыто 2 марта 1892 г., а инициатором открытия общества стал местный учитель церковно-приходской школы А. А. Ватковский. В общество входило 10 человек. Участник давали в церкви обет трезвости на год и более продолжительный срок. После произнесенных клятв священник благословлял иконой нового члена и записывал его имя в «книгу трезвости» $[18$, c. $18-19]$.

В губернии существовали и частые Общества трезвости. Например, в селе Америно, Стародубского уезда Орловской губернии сами крестьяне решили в 1891 г организовать общество трезвости. В данное общество вошло 25 человек [16, с. 27].

Основной целью общества трезвости было любой ценой отвлечь народ от употребления алкоголя. По стране стали массово открывать чайные и столовые, дома трудолюбия. Особой популярностью в борьбе с пьянством стало популяризация прогулок на свежем воздухе, посещения театров. В этот период особо востребованными становятся народные театры

Церковь брала на себя просветительскую работу. В Епархиальных ведомостях стали чаще появляться рассказы о вреде алкоголя. В Орловских ведомостях за 1898 г. есть интересная статья «Казенная продажа питец». В ней автор сообщает, что в России «самая маленькая деревня имела своего дельца - кабатчика, который без разбора пользовался всякими способами, чтобы побольше нажить на своем промысле и на крестьянской слабости) $[9$, с. 1490].

Церковь разъясняла народу через статью, - вреде чрезмерного употребления алкоголя. В статье дается объяснение причин принятия антиалкогольного закона 1895 г.: «дозволявший торговать водкою распивочно только в трактирах, где к пятью подается и закуска; распивочные кабаки были вовсе уничтожены, а вместо них заведены винные лавки, откуда можно было брать водку только на вынос». Автор считает, что так «меньше соблазна» для пьянства. Эта мера оказалась не результативной.

С 1 января 1895 г. в четырех восточных губерниях вводится «казенная продажа питья». Автор подчеркивает, что винная монополия стала охватывать все большое количество губерний, пока не распространилась по всей стране. Читателю дается четкое разъяснение пользы от данного закона: «дать возможность потреблять вместо прежнего, плохо очищенного вина, совершенно чистый, насколько можно, безвредный напиток» [9, с. 1492]. Изменения коснулись не только качества напитка, но и его цены. «В казенной продаже нет разницы между оптовою и раздробительною ценой... Это сделано для того, чтобы не соблазнялся выгодно купить побольше водки, а брал бы

. столько, сколько ему сейчас нужно») [9, с.1493].

В стране вводится четкий период продажи вина. По будням - не раньше, чем с 7 часов утра и до 10 часов вечера. В сельской местности разрешалась продажа в летнее-весенний период до 10 вчера, а в остальной период - до 8 часов вечера. По праздникам торговали после окончания литургии.

Законопроект предусматривал и наказание за несоблюдение означенных правил. В случае нарушения требований к таре и завышения цены на казенную водку продавец должен возместить штраф в размере 100 рублей. Если кто-то пожелает провести спиртное из других губерний для торговли, где закон не еще не действует, с нарушителя снимается «тройная стоимость привезенных продуктов».

Для организации помощи народу в борьбе с алкоголезависимостью в уездных городах создаются «попечительства о народной трезвости», а в губернских городах - главные комитеты под предводительством губернатора. Членами данных организаций мог стать любой желающий, который своим примером пропагандирует образ жизни трезвого человека. Члены общества имели право посещать питейные заведения с целью контроля их работы, распространять литературу о вреде пьянства, вести просветительские беседы.

Введение винной монополии планировалось поэтапно. С 1 июля 1896 г. казенная продажа вина, и организация попечительств о народной трезвости были введены в девяти губерниях: Бессарабской, Волынской, Екатеринославской, Киевской, Подольской, Полтавский, Таврической, Херсонской и Черниговской. Уже через год монополия распространилась на западные губернии: Виленскую, Витебскую, Гродненскую, Ковенскую, Минскую, Могилевскую, Смоленскую. А 1 января 1898 г. к реформе присоединились Новгородская, Олонецкая, Псковская, Санкт-Петербургская, Харьковская и десять губерний Царства Польского. В 1900 г. монополия вводится в Курляндской, Лифляндской, Эстляндской, Воронежской, Курской, Ставропольской, Черноморской областях и в области войск Донского. В 1901 г. к ним присоединились: Архангельская, Вологодская, Вятская, Казанская, Пензенская, Симбирская, Саратовская, Астраханская губернии и области Уральская и Тургайская. С июля 1902 г. винная монополия стала проводиться и на территории Владимирской, Костромской, Московский, Нижегородской, Рязанской, Тамбовской, Тверской, 
Тульской, Ярославской и Орловской губерний [9 c. 1500]. Таким образом, казенная продажа спиртных напитков к 1903 г. будет распространена по всей территории России.

В Орловской губернии работал губернский комитет попечительства о народной трезвости. Его председателем был губернатор. Почетным членом общества являлся священник Брянцев. В состав общества входили представители от прокуратуры окружного суда, губернские предводители дворянства и многие другие. Из духовного ведомства - епархиальный наблюдатель школ С. Н. Савинов и протоиерей М. Крылов. Вобществе состояли военные: командир 142 пехотного Звенигородского полка и член от губернского земского собрания статский советник Николай Петрович Римский-Корсаков, коллежский асессор И. П. Купчинов $[9$, с. 1490$]$.

В борьбе с алкоголем помогали дома трудолюбия. В Орловской губернии существовали три общества: Попечительское общество Дома трудолюбия в Орле (1888), Попечительское общество Дома трудолюбия в Ельце (1896), Попечительское общество Дома трудолюбия в Мценске (1898) [5, c. 19-20].

В 1891 г. в г. Орле по инициативе местного купца Павла Дмитриевича Бакина открывается дом трудолюбия. В 1897 г. при доме трудолюбия была построена церковь Александры Царицы. На территории Дома трудолюбия имелись ночлежка, богадельня, детский приют и мастерские [21].

В состав членов попечительного общества Орловского дома трудолюбия входили представители различных населенных пунктов губернии Председательствовал в обществе Михаил Александрович Стахович из г. Ельца. Работу общества также организовывали М. А. Барманская, Н. Д. Панов, врач Ф. О. Гаусман, священник В. В. Воскресенский и многие другие.

При доме трудолюбия имелись:

- церковь (священник И. П. Баженов, псаломщик Ф. Ф. Иванов);

- приют «Ясли» (заведовала А. Н. Гирей);

- хлебопекарня (заведовал А. И. Янушковский):

- чулочная и белошвейная мастерская (заведовала О.И. Денисова)

- убежище для мальчиков

- убежище для девочек;

- учебно-столярская мастерская;

- богадельня;

- дешёвая столовая;

- ночлежный приют;

- проводился сбор ненужных вещей (им руководило Правление попечительного общества)

Многие люди не только личным примером, но и с помощью активной пропаганды трезвого образа жизни стремились помочь народу. Церковь поддерживала эти общественные начинания Так, например, на страницах Орловских епархиальных ведомостей за 1917 г. содержится официальное поздравление учителя И. Ф. Прохорова Козинской церковно-приходской школы Ливенского уезда. Наряду с педагогическими и воспитательными успехами учителя местный священник
А. Н. Казанский подчеркивает и еще одну важную заслугу. В свои 25 лет Прохоров вел активную работу среди прихожан по искоренению «в сердцах детей грубыя привычки». Учитель Прохоров был одним из первых, кто откликнулся на предложение священника создать в селе Козинке общество трезвости, проведении трезвых собраний среди взрослого населения [14, с. 91].

Елецкое Аргамаченское общество в 1913 г. получили за свои экспонаты, представленные на итальянской выставке в Турине, большую золотую медаль «за целесообразную и высоко полезную организацию борьбы с алкоголизмом) [13, с. 48].

Данное общество возникло 15 марта 1898 г по инициативе местного священника Аргамаченской церкви Рождества Пресвятой Богородицы Николая Брянцева. В состав общества входило: «... 702 мужчины, 9 женщин, 478 грамотных, 237 неграмотных: по сословию 3 дворянина, 9 духовных, 14 почетных граждан, 212 мещан и 473 крестьян. По занятиям выдающееся число было земледельцев - 223 человека, сапожников - 73 человека, торговцев - 68 человек, каменотесов 51 человек, посадчиков 48, слесарей 31 человек, кузнецов 23 человека и портных $21 »[4$, с. 64].

Деятельность общества трезвости была направлена на отказ от алкоголя и приобщение людей к посещению чайных, читален. Общество занималось распространением специальной литературы о вреде пьянства, раздавало листы и брошюры, устраивала спектакли и концерты.

Орловская епархия подготовила список рекомендованной антиалкогольной литературы. Среди множества книг можно выделить: книгу Антония (игумен). «Пьянство и курение табаку и их вредные последствия» (1904); «Беседа о пьянстве, с рисунками желудка» (1902); «Водка до всего доведет» (1910); «Грех и безумие пьянства. Сборник поучений против пьянства» (1892); «Дружеский совет: как отстать от окаянного пьянства и проклятого запоя» (1909); «Как отстать от спиртных напитков» (1910); “К вопросу о пьянстве. Составлен по немецким источникам» (1896); «Пьянствовеликоезло»(1904)идругие[10, с. 12221224]. Данная литература была недорогой и ее рекомендовалось закупать и распространять в приходе.

Активная позиция священнослужителей Орловской епархии принесли свои положительные плоды. Так, например, чайная Аргамаченского общества трезвости стала для крестьян местом досуга. Ее посещали не только мужчины, а целые семьи. В 1907 г. по инициативе заведующего Лучковской чайной г. Ельца и комитета по народной трезвости создается очередная читальня при чайной. Организовывали и медицинскую помощь. В 1909 г. в Елецкой больнице открыли приемные покои (вытрезвители) и проводили медикаментозное лечение алкоголиков. Многие члены приходских обществ трезвости Орловской губернии вели просветительскую работу о вреде пьянства, создавали спектакли и проводили праздники трезвости, принимали участие в выставках. Опыт организации борьбы с пьянством был признан 
положительным и заимствовался в других епархиях. Так, например, Епископ Екатеринбургский и Ирбитский Макарий на заседании членов Екатеринбургской духовной консистории 9 июля 1910 г сообщал о достижениях Орловской епархии.

По сообщению Владыки в Орловской епархии применяли следующие меры: «Перед наступлением Великого поста священники с церковного амвона начинали призывать народ к трезвости, хотя на время св. четыредесятницы и пасхальной недели, убеждали давать обеты и сами на себя принимали такие же обеты и исполняли их) [8, c. 578-579].

В Орловских епархиальных ведомостях за 1910 г. содержится отчет о пастырском собрании в Орле. В здании епархиального женского училища уездное пастырское собрание обсуждало с мирянами вопрос о мерах, применяемых в приходах против пьянства. Настоятель Орловской Успенской церкви М. И. Крылов сообщал, что члены приходского совета разделили между собой территорию прихода для того, чтобы следить за распространением пьянства.

Епископ Митрофан предложил прихожанам воспользоваться опытом Елецких обществ трезвости - Аргамаченского и Владимирского. Членам Успенского прихода было выделено 25 руб. для приобретения противоалкогольной литературы $[12$, с. 124].

В селе Богородицком в Буковищах отец А. Д. Емельянов совместно с 5-6 молодыми членами прихода организовывал служение всеношных бдений. Односельчане активно посещали службы, многие, желая дать обет совершенного отречения от употребления спиртных напитков, получали от священника наставления и благословление. Итоги антиалкогольной работы молодого священника в селе Богородицком пастырство признало положительным.

Священник Иверской привокзальной церкви отец А. Н. Оболенский проводил активную просветительскую работу среди прихожан, «выступал против питья спиртных напитков на поминальных обедах и вообще трапезах, устраиваемых прихожанами на разных требах» $[12$, с. 124]

Распространение антиалкогольных движений в стране стало повсеместным. В 1914 г. император Николай II вводит запрет на продажу водки. Если первоначально эта мера была временной, то постепенно она вошла в обиход и общество стало ограничивать себя в употреблении спиртного. Такими радикальными мерами и положительными результатами не могла похвастаться ни одна Европейская держава. Таким образом, благодаря совместным усилиям церкви и государства удалось не только на уровне законодательной системы побороть пьянство, но и изменить само отношение народа к этой проблеме. Опыт воспитательной работы, проводимой церковью имел положительные результаты. В молодое поколение удалось вложить нравственные ориентиры и дать возможность изменить условия своего существования. Полученные результаты антиалкогольной борьбы дореволюционной России оказались востребованы и в советском обществе, многие принципы, такие, как убеждение, беседы, привлечение общественности, клятва и обещания стали популярны в СССР. Уже в 1925 г. советская власть восстанавливает государственную винную монополию, возрождает работу движения за трезвость под новым названием - антиалкогольное и стремиться воспитать трезвую молодежь. 16 февраля 1928 г. было создано «Общество борьбы с алкоголизмом». Борьба с пьянством в советском обществе зародилась в народе и только после его возглавила партия. Через убеждение и идеологические принципы власть вела борьбу с алкогольным разгулом. Именно в этом и видится преемственность дореволюционного метода, только инициативу народа поддерживало духовенство и посредством веры лечило народ. Сегодня наша страна вновь столкнулась с «модой на пьянство». Необходимо изучать и активно внедрять ранее накопленные результаты антиалкогольных компаний.

\section{Источники и литература}

1. Александро-Невское общество трезвости в Санкт-Петербурге. URL: http://www.encspb.ru/object/ (Дата обращения: 20.09.2018)

2. Афанасьев А. Л. Всероссийские съезды по борьбе с пьянством, III Государственная Дума и трезвенное движение в Сибири и на Дальнем Востоке в 1910-1912 гг. // Вестник Томского государственного университета. 2010. №335. C.63-67.

3. Безгин В. Крестьянская повседневность (традиции конца XIX - начала XX века). М. - Тамбов: Издательство ТГTУ, 2004. $304 \mathrm{c}$.

4. Гринченко Н. А., Ляпин Д. А. Трезвый Елец. Елец: ЕГУ им. И. А. Бунина, 2013. 153 с.

5. Гуларян А. Б. Развитие системы благотворительности в Росссийской империи (на примере Орловской губернии) // Ученые записки Орловского государственного университета. 2014. №4(60). С.15-21.

6. Гусев Г. В. Общество трезвости как учреждение внешкогльного дополнительного образования (конец XIX - начале XX вв.) // Вестник ПСТГУ IV: Педагогика. Психология. 2010. Вып.1(16). С. 63-76.

7. Девять писем С. А. Рачинского о трезвости. Публ. 1904 г. // Вестник Трезвости, август 1904 г. № 116. С. 27-35.

URL: http://www.proza.ru/2016/11/15/46 (Дата обращения: 20. 09.2018)

8. Екатеринбургские епархиальные ведомости за 1910. Екатеринбург, 1910. №28.

9. Орловские епархиальные ведомости за 1898. 1898. №40. 1598 с.

10. Орловские епархиальные ведомости за 1909. 1909. №49. 1230 с.

11. Орловские епархиальные ведомости за 1910. 1910. №5. 32 с.

12. Орловские епархиальные ведомости за 1910. 1910. №35. 948 с. 
13. Орловские епархиальные ведомости за 1914. 1914. №2. 62 с

14. Орловские епархиальные ведомости за 1917. 1917. №5/6. 52 с

15. Памятная книжка Орловской губернии на 1898 г. Орел: Типография губернского правления, 1898.72 с.

16. Памятная книга. Адрес-Календарь Орловской губернии на 1909 г. Орел: [б.и.], 1908. 405 с.

17. Прыжов И. Г. История кабаков в России в связи с историей русского народа M.: Наследие, 2009. URL: http:// statehistory.ru/books (Дата обращения: 21. 09.2018)

18. Русское общество трезвости, их организация и деятельность в 1892-1893 гг. / сост. Н. И. Григорьев. СПб.: [б.и.], 1894. $83 \mathrm{C}$.

19. Священномученик Серафим Чичагов. О возрождении приходской жизни. URL: http://nikolahram.com/item (Дата обращения: 21.09 .2018$)$

20. Седова О. В. Повседневная жизнь русского духовенства конца XIX- начала XX вв. в повести Д.Г. Булгаковского «В стороне от жизни» // История: Факты и символы. 2018. №15. С.17-24.

21. Храмы России. URL: http://temples.ru/card (Дата обращения: 20.09.2018).

\section{References}

1. Aleksandro-Nevskoe obshchestvo trezvosti v Sankt-Peterburge (Alexander Nevsky's sobriety society in Saint Petersburg). URL: http://www.encspb.ru/object/ (Accessed: 20. 09.2018) (In Russian).

2. Afanas'ev A. L. Vserossijskie s»ezdy po bor'be s p'yanstvom, III Gosudarstvennaya Duma i trezvennoe dvizhenie $v$ Sibiri i na Dal'nem Vostoke v 1910-1912 gg. (Al/-Russian Congresses on the Fight Against Drunkenness, III State Duma and the Sober Movement in Siberia and the Far East in 1910-1912) // Vestnik Tomskogo gosudarstvennogo universiteta. 2010. No.335. P. 63-67. (In Russian).

3. Bezgin V. Krest'yanskaya povsednevnost' (tradicii konca XIX - nachala HKH veka) (Peasant Everyday Life (Traditions of the Late XIX - Early XX Century). Moscow - Tambov: TSTU publ., 2004. 304 p. (In Russian).

4. Grinchenko N. A., Lyapin D. A. Trezvyj Elec (Sober Elec). Elec: ESU named after. I.A. Bunin publ., 2013. 153 p. (In Russian).

5. Gularyan A. B. Razvitie sistemy blagotvoritel'nosti v Rosssijskoj imperii (na primere Orlovskoj gubernii) (Development of Charity System in the Russian Empire (by the Example of the Orel Province)) //Uchenye zapiski Orlovskogo gosudarstvennogo universiteta. 2014. No. 4(60). P.15-21. (In Russian).

6. Gusev G. V. Obshchestvo trezvosti kak uchrezhdenie vneshkogl'nogo dopolnitel'nogo obrazovaniya (konec XIX nachale HKH vv.) (Sobriety Society as an Institution of Extra-Curricular Education (Late XIX - Early XX Centuries)) // Vestnik PSTGU IV: Pedagogika. Psihologiya. 2010. Issue 1(16). P. 63-76. (In Russian).

7. Devyat' pisem S. A. Rachinskogo o trezvosti (Nine Letters of S. A. Rachinsky About Sobriety). Publ. $1904 \mathrm{~g}$. // Vestnik Trezvosti. 1904. No.116. P. 27-35. URL: http://www.proza.ru/2016/11/15/46 (Accessed: 20. 09.2018) (In Russian).

8. Ekaterinburgskie eparhial'nye vedomosti za 1910 (The Yekaterinburg Diocesan Gazette of 1910). Ekaterinburg, 1910 No. 28. (In Russian).

9. Orlovskie eparhial'nye vedomosti za 1898 (Orel Diocesan Statements of 1898). 1898. No.40. 1598 p. (In Russian).

10. Orlovskie eparhial'nye vedomosti za 1909 (Orel Diocesan Statements of 1909). 1909. No. 49.1230 p. (In Russian)

11. Orlovskie eparhial'nye vedomosti za 1910 (Orel Diocesan Statements of 1910).1910. No. 5. 32 p. (In Russian).

12. Orlovskie eparhial'nye vedomosti za 1910 (Orel Diocesan Statements of 1910). 1910. No. 35.948 p. (In Russian).

13. Orlovskie eparhial'nye vedomosti za 1914 (Orel Diocesan Statements of 1914). 1914. No. 2. 62 p. (In Russian).

14. Orlovskie eparhial'nye vedomosti za 1917 (Orel Diocesan Statements of 1917). 1917. No. 5/6. 52 p. (In Russian)

15. Pamyatnaya knizhka Orlovskoj gubernii na $1898 \mathrm{~g}$. (The Memorable Book of the Oryol Province in 1898). Orel: Tipografiya gubernskogo pravleniya, 1898.72 p. (In Russian).

16. Pamyatnaya kniga. Adres-Kalendar' Orlovskoj gubernii na $1909 \mathrm{~g}$. (Book of Remembrance. The Address-Calendar of the Oryol Province in 1909). Orel, 1908. 405 p. (In Russian).

17. Pryzhov I. G. Istoriya kabakov v Rossii v svyazi s istoriej russkogo naroda (The History of Taverns in Russia in Connection with the History of the Russian People). Moscow: Nasledie, 2009. URL: http://statehistory.ru/books (Accessed: 21. 09.2018) (In Russian).

18. Russkoe obshchestvo trezvosti, ih organizaciya i deyatel'nost' v 1892-1893 gg. (Russian Society of Sobriety, Their Organization and Activities in 1892-1893). St.Petersburg, 1894. 83 p. (In Russian).

19. Svyashchennomuchenik Serafim Chichagov. O vozrozhdenii prihodskoj zhizni (The Revival of Parish Life). URL: http:// nikolahram.com/item (Accessed: 21. 09.2018) (In Russian).

20. Sedova O. V. Povsednevnaya zhizn' russkogo duhovenstva konca XIX - nachala XX vv. v povesti D. G. Bulgakovskogo " $V$ storone ot zhizni» (The Everyday Life of the Russian Clergy in the Late XIX - Early XX Centuries in the story of D. G. Bulgakovskiy "Away from Life") // Fakty i simvoly. 2018, No. 15. P.17-24. (In Russian).

21. Hramy Rossii (The Churches Of Russia). URL: http://temples.ru/card (Accessed: 20.09.2018) (In Russian).

\section{Сведения об авторе}

Клевцова Оксана Владимировна - кандидат исторических наук, доцент кафедры истории и историко-культурного наследия Елецкого государственного университета им. И. В. Бунина (Елец) / ksenijmel@ yandex.ru

\section{Information about the author}

Klevtsova Oksana - PhD in History, Associate Professor, Chair of history and Historical and Cultural Heritage, Yelets State University named after I. A. Bunin (Yelets) / ksenijmel@yandex.ru 